\section{LATE MEDIEVAL TRINITARIAN \\ SYLLOGISTICS: FROM THE \\ THEOLOGICAL DEBATES TO A \\ LOGICAL TEXTBOOK}

\section{Paloma Pérez-Ilzarbe}

University of Navarra

Pamplona, Spain

pilzarbe@unav.es

Jerónimo Pardo's analysis of the problems raised by some popular trinitarian paralogisms is studied in this paper. The purpose is to show how the notions employed by the theologians in order to solve theological problems were introduced into a textbook on logic to deal with some genuinely logical problems. First, the problem, common to all logical approaches, of achieving a fine-grained analysis of the logical form of syllogistical inferences. Second, the problem, typical of the terminist approach to logic, of guaranteeing that Latin is an adequate vehicle for logical analysis.

\section{Terminist logic and the Trinity: some late-medieval theologians in a} post-medieval textbook on logic

Many studies have been devoted to showing the various aspects of the influence of medieval logic in Christian theology (see, for example, the works cited in [4, p. 183]). Thanks to these, we know how some medieval logical tools were applied to theological discussions. A widely studied topic is the application of the medieval theory of the 'properties of terms' (proprietates terminorum) to the specific problems generated by the complexity of trinitarian theology ([1], [2], [6] - [9], [10]).
The Catholic doctrine of the Trinity (with a God who is one simple Essence and at the same time three Persons with different properties) is found to produce some paradoxes when it is arranged in accordance with the patterns of Aristotelian syllogistics. The terms used in trinitarian contexts ('Essentia divina,' 'Pater,' 'Filius,' 'Trinitas,' 'generans,' 'spirans'...) allow us to construct some syllogisms which seem to follow the rules of Aristotelian logic but also seem to have true premises and a false conclusion. Among other responses, one very influential one lies in applying to the problematic cases the analytical tools provided by the theory of the proprietates terminorum. We can see this practice in the works of some brilliant theologians of the fourteenth century, such as Gregory of Rimini, Adam Wodeham and Peter of Ailly.

These theologians saw the notions and distinctions belonging to the theory of the proprietates terminorum as a means to save the rationality of their theological discourse. But the connection logic-theology can be seen the other way round: not from the perspective of the theologians, but from the perspective of the logicians, who are confronted with a new domain of application for a well established and accepted logical doctrine. This is the perspective that I will examine.

I will base my analyses on the work of a post-medieval logician, the Spaniard Jerónimo Pardo, who was a master of Arts and bachelor in Theology at the University of Paris at the very end of the fifteenth century. His Medulla Dyalectices (printed in Paris in 1500, and reprinted shortly after Pardo's death in 1505) ${ }^{1}$ offers a privileged viewpoint to look at the discussions that took place more than a century before. Pardo is transferring the logical discussions that were placed in a theological context to their proper context, that of logic. In this context, the doctrinal concerns are no longer present, so Pardo is able to assess each notion and distinction on its own, just in terms of its logical value. ${ }^{2}$

\footnotetext{
There is no modern edition of this work. I will quote from the 1505 edition, referring to it as $M D$. A provisional transcription of the relevant passages can be found at http://www.unav.es/filosofia/pilzarbe1/medulla_dyalectices/medulla_dyalectices.html ${ }^{2}$ Sometimes Pardo gives the name of the theologian who employed the notion he is discussing (and, for example, he quotes literally some passages from Gregory's and Peter's commentaries on the Sentences), but most of the time the author of the opinion is not identified but hidden under the expressions 'aliqui dicunt,' 'alii dicunt,'
} 
Terminist logic was re-flourishig at that moment at the University of Paris, and Pardo was firmly convinced that it was the correct tool to carry ou logical analyses. As far as syllogistical inference is concerned, the chapter De Syllogismis is fully devoted to show how the theory of the properties of terms can be used to dissolve any counterexample that might seem to threaten the Aristotelian doctrine. In this context, the different trinitarian paralogisms that were discussed in the theological works are just providing some examples of propositions that can be used to test the power of the terminist techniques of analysis. ${ }^{3}$

\section{Jerónimo Pardo's theory of the syllogism: in search of the logica form}

Chapter nine of Pardo's Medulla Dyalectices focuses on the categorical syllogism, which is defined as a kind of formal consequence. Being a formal consequence, the validity of a syllogism should be characterized independently of any content. To this end, Pardo gives the Aristotelian rules dici de omni and dici de nullo a prominent role, as being the regulative principles of any categorical syllogism. ${ }^{4}$

In Pardo's words, this is the condition that a syllogism has to meet in order to be immediately governed by the principle dici de omni:

Dici de omni: A syllogism is immediately governed by the dici de omni when nothing can be subsumed under the distributed subject of the major

'communiter solet poni,' etc. A further task to be done, which lies beyond the scope of this article, is that of identifying the supporters of every notion and distinction.

${ }_{3}^{3}$ Pardo's Medulla can thus be added to the list given in [5, p. 70] of post-medieval textbooks which use some trinitarian paralogisms in discussing the syllogism.

${ }^{4}$ Omnis autem talis sillogismus altera duarum regularum necesse est regulari: aut enim est affirmativus, et sic regulandus est per dici de omni, aut negativus, et sic regulandus est per dici de nullo. Que dicuntur principia regulativa sillogismorum tanta et talia, ut omnis sillogismus qui altera duarum regularum regulantur bonus et regularis dicatur et econverso, omnis autem qui altera harum regularum non regulatur, irregularis et inordinatus est dicendus et econverso. Ideo, omnem bonum sillogismum necesse est alteri harum regularum se conformare et omnem malum alicui harum se difformare; et ut unico complectatur verbo, cuiuslibet mali sillogismi solutio hec debet esse: quia non regulatur per dici de omni aut per dici de nullo (MD, fo. $126 \mathrm{va})$. premise, of which the predicate of the major premise is not also affirmed in the conclusion.

This happens when a) the major premise is a universal affirmative proposition, by means of which the predicate is affirmed of everything that the subject is said of; b) in the minor premise the subject of the major one is said of something, these things being then 'subsumed' under that term; and c) in the conclusion the predicate of the major premise is said of (at least some of) the things that were subsumed in the minor premise. For example, if we affirm in the major premise that every human being is an animal, and then in the second premise we subsume something, say Socrates, under 'human being,' then we are allowed in the conclusion to say of Socrates that he is an animal. ${ }^{5}$

In order for a syllogism to be immediately governed by the principle dici de omni, the major premise has to be de omni, that is, it has to affirm the predicate of whatever the subject is said of. This is usually accounted for in terms of distributio, which is the kind of suppositio that corresponds to the terms in the scope of a universal syncategorem, such as 'omnis.'

The principle dici de nullo is analogously formulated and explained for the case of universal negative propositions. Pardo affirms that for any good syllogism we should be able to show that it is governed (either immediately or mediately) by one of these principles, and that for any bad syllogism we should be able to show how it is not governed by any of them. Let me summarise Pardo's proposal by the following General Rule:

General Rule: A necessary and sufficient condition for the validity of a syllogism is that it is governed (either immediately or mediately) by the dici de omni or dici de nullo.

${ }^{5}$ Unde sillogismus regulatur immediate per dici de omni quando nichil est sumere sub subiecto distributo maioris de quo non denotetur dici predicatum maioris in conclusione; ita quod in maiori propositione denotatur predicatum dici affirmative de quocunque dicitur subiectum, et in minore denotatur subiectum maioris dici de aliquo assumpto in minore, et in conclusione denotatur predicatum maioris dici de aliquo quod assumebatur in minore. Ut si dicam: omnis homo est animal, denotatur quod de quocunque verum est dicere quod est homo verum est dicere quod est animal; in hac minore: sed Sortes est homo, ly homo denotatur dici de aliquo; inferendo: ergo Sortes est animal, ly animal denotatur dici de illo assumpto in minori (MD, fo. 126va). 
Pardo devotes almost a half of the chapter De Sillogismis to discussing the moods Barbara and Darii, as they are immediately governed by the principle dici de omni, so they have (along with Celarent and Ferio, immediately governed by the dici de nullo) a founding character with respect to the remaining valid moods. His discussion always takes the same path: he starts by presenting some counterexamples (that is, some syllogisms that seem to have the form of one or other valid mood, but that seem to have true premises and a false conclusion, which is prohibited in the case of a valid inference); he then defines the logical notions and introduces the distinctions that he deems relevant for the solution; and he finally solves the counterexample by showing, with the help of the previously established notions and distinctions, either that the alleged syllogism is defective in its form or that, though it has the correct form, one of the premises is not true. The solutions proposed for the basic moods are taken as a model for the remaining moods, which Pardo does not analyse in such detail.

As is stated above, Pardo entrusts the solution of the different paralogisms to various terminist theories (namely, the ones of suppositio, appellatio and ampliatio). The terminist notions and distinctions are thus used as a tool to safeguard the formal character of the syllogistical inference. In this context, many cases of trinitarian syllogisms are presented, as the peculiar semantics of the divine terms raises some special problems for the terminist approach to the Aristotelian theory of the syllogism.

As a matter of fact, the first counterexample that Pardo offers is a syllogism with trinitarian terms, which seems to have a Barbara-form but where the conclusion does not seem to follow from the premises (since, according to orthodoxy, the premises are true and the conclusion is false):

(1) Omnis Essentia divina est Pater, omnis Filius est Essentia divina, ergo omnis Filius est Pater.

Every divine Essence is the Father, every Son is the divine Essence, therefore every Son is the Father.
Should this syllogism indeed have a Barbara-form, it would be governed by the principle dici de omni. That is, in the major premise one would be denoting that of whatever the subject is said, of the same thing the predicate is said; and in the minor premise one would be denoting that the subject of the major one is said of something; then, in the conclusion one would be denoting that the predicate of the major premise is said of the same thing that has been subsumed in the minor one. So, the application of the General Rule simply dissolves the paralogism, as we have the following two possibilities: either 'omnis Essentia divina est Pater' is de omni, and then the syllogism is a valid one, but the major premise is false (and thus it is not a problem that the conclusion is also false); or 'omnis Essentia divina est Pater' is not de omni, and then the syllogism is an invalid one (and thus it is not a problem that the premises are true and the conclusion is false). ${ }^{6}$

The possibility that the universal proposition 'omnis Essentia divina est Pater' is not de omni is allowed by the peculiar semantics of the divine terms. The term 'Essentia divina' can be said not only of the very divine Essence, but also of each of the divine Persons. If the predicate 'Pater' in 'omnis Essentia divina est Pater' is predicated of the divine Essence but not of each divine Person, this proposition cannot be said to be de omni. This means that, as far as trinitarian propositions are concerned, the syncategorem 'omnis,' which was usually considered to suffice to effect the required distribution in order for a syllogism to be governed by the dici de omni, seems to be no longer sufficient. The schema:

B1. Omne A est B,

omne $\mathrm{C}$ est $\mathrm{A}$,

ergo omne $\mathrm{C}$ est $\mathrm{B}$,

${ }^{6}$ Dicendum enim est illos sillogismos esse bonos si regulantur per dici de omni, ita quod in maiori denotetur quod de quocunque dicitur subiectum dicitur predicatum et in minori de aliquo denotetur dici subiectum, in conclusione vero de eodem denotetur dici predicatum. Sed maior est falsa in qua dicitur omnis essentia divina est pater quia non de quocumque verum est dicere quod est essentia divina de eodem verum est dicere quod est pater, nam filius est essentia divina et tamen filius non est pater. Ideo, dicentes illum sillogismum bonum esse si maior sit de omni recte solvunt, si enim maior non est de omni non regulatur mediate per dici de omni, maior enim debet esse regula de omni secundum quam maior et conclusio sunt regulande (MD, fo. 127ra). 
Every A is B,

every $\mathrm{C}$ is $\mathrm{A}$,

therefore every $\mathrm{C}$ is $\mathrm{B}$,

which could at first sight be considered as capturing the structure of the mood Barbara, is shown by the trinitarian counterexample to be an inadequate anlysis of the Barbara-form.

The trinitarian domain is putting a high level of demand on the formality of consequences. If Pardo wants the syllogistic mood Barbara to be a formal consequence, he needs to go deeper into specifying its logical form. The notions and distinctions that Pardo is importing from the theological debates find in the Medulla their natural place, as they are introduced in successive steps to achieve a better grasp of the logical form.

\section{Proprietates terminorum and syllogistical form: the notion of distributio completa}

Let us go back to example (1). In the minor premise, the peculiar semantics of the divine terms allows one to predicate 'Essentia divina' of 'Filius.' But in order for the syllogism to be governed by the dici de omni, the major premise must affirm the predicate of whatever the subject is said of. This raises a question concerning the universality of the major premise: when we say 'omnis Essentia divina est Pater,' are we affirming 'est Pater' of the Son? The theory of the proprietates terminorum allowed the theologians to put the question in semantic terms, either in terms of distribution, or in terms of supposition. That is, one can ask: is the term 'Essentia divina' distributed to the divine Son? Or: does the term 'Essentia divina' supposit for the divine Son? The answers are used by Pardo to elaborate a more accurate notion of syllogistical form.

In order to find an answer that dissolves the paralogism, the theologians introduced a distinction between two forms of distribution of the divine terms: complete and incomplete. A universal proposition with complete distribution has stronger truth-conditions than a universal proposition with incomplete distribution. Pardo characterises these notions in terms of the notion of inferior, which is part of the terminist technique for specifying the truth-conditions of quantified propositions, the descensus to singulars: from a quantified proposition one can descend to a set of singular propositions, in which the predicate is said of the inferiora of the common term. But, again, the setting of the inferiora of the trinitarian terms is affected by their particular semantic behaviour. Pardo distinguishes two kinds of inferiora for the divine terms: per se and non-per se. For example, he explains that the term 'Essentia divina' has only one inferior per se, namely 'haec Essentia divina que est Pater et Filius et Spiritus Sanctus,' although in a non-per se sense, 'Filius' can also be considered to be an inferior of that term.

Pardo thus formulates the distinction between complete distribution and incomplete distribution in the following terms:

- For a universal proposition in which there is a complete distribution to be true, it is required that the predicate is truly said of everything that the subject is said of, whether it is per se under the subject or it is not.

- For a universal proposition in which there is an incomplete distribution to be true, it is sufficient that the predicate is truly said of everything that is per se under the subject. ${ }^{7}$

This means that, in order for the syllogism to be governed by the dici de omni, the subject of the major premise has to be distributed with complete distribution. The domain of the Trinity has thus shown that there are (at least) two kinds of universality, one that suffices for the mood Barbara to be a formal consequence and one that does not suffice. Thus, the General Rule can be specified for the case of the mood Barbara by means of the following formulation:

Rule 1: A necessary condition for the validity of a Barbara syllogism is that the subject of the major premise ' $A$ ' is distributed to everything that is A (omne quod est A).

${ }^{7}$ Ad veritatem enim universalis in qua est distributio completa requiritur quod de quocunque dicitur subiectum de illo dicatur predicatum sive illud sit per se contentum sub subiecto sive non. Sed ad veritatem propositionis universalis cuius subiectum distribuitur distributione incompleta sufficit predicatum dici de omni per se contento sub subiecto (MD, fo. $127 \mathrm{ra}-\mathrm{b})$. 
The structure of the mood Barbara could then be better expressed by the schema:

B2. Omne quod est A est B, omne $\mathrm{C}$ est $\mathrm{A}$, ergo omne $\mathrm{C}$ est $\mathrm{B}$.

Everything that is $\mathrm{A}$ is $\mathrm{B}$, every $\mathrm{C}$ is $\mathrm{A}$,

therefore every $\mathrm{C}$ is $\mathrm{B}$.

Of course, this distinction does not have any effect in the domain of the creatures (unless, says Pardo, one accepts Scotus' proposal of some naturas communes per indifferentiam), but it has to be posited if one wants the syllogistical consequence to hold independently of any matter. However, a further counterexample is going to require a finer analysis of the logical form.

\section{The correct reading of the universal proposition}

Pardo also considers the following example of a syllogism with trinitarian terms:

(2) Omnis Essentia divina est Persona,

Trinitas est Essentia divina,

ergo Trinitas est Persona.

Every divine Essence is a Person,

the Trinity is the divine Essence,

therefore the Trinity is a Person.

Even if we apply the previous analysis, the paralogism does not seem to dissolve. If we read the major premise as 'omne quod est Essentia divina est Persona' according to its de omni sense, it is still a true premise, and, when joined to the minor premise which is also true, it allows us to draw a false conclusion in accordance with the Darii-form.
Pardo reports that this problem has led some theologians to say that a special kind of supposition is present here, namely a supposition extra numerum, as opposed to the supposition in numero, ${ }^{8}$ grounded on the fact that although whatever is the divine Essence is a Person (omne quod est Essentia divina est Persona), nevertheless not all things that are the divine Essence are a Person (non omnia que sunt Essentia divina sunt Persona), because three Persons are the divine Essence but they are not a Person. The solution of the paralogism involves the contrast between 'omne quod est Essentia divina est Persona,' which expresses the in numero sense of the major premise, and 'omnia que sunt Essentia divina sunt Persona,' which expresses the extra numerum sense.

But Pardo does not consider that this distinction is necessary to dissolve the paralogism. All that is needed is a better reading of the de omni sense of the universal proposition 'omnis Essentia divina est Persona.' In the light of example (2), we can see that the expression 'omne quod est' does not provide a correct reading of the complete distribution. Instead, the expression 'omne ens quod est' has to be used. This allows us to solve the paralogism in analogy with (1), by showing that, when taken in its de omni sense, the major premise is false. 'Omne ens quod est Essentia divina est Persona' is a false proposition, because the Trinity is in fact a being which is the divine Essence (as the Trinity is the very divine Essence, which is of course a being which is the divine Essence), but the Trinity is not a Person. ${ }^{9}$ The 'ens' has the effect of fully extensionalising the analysis, thus avoiding the problems derived from the peculiar semantics of the trinitarian terms. ${ }^{10}$

This allows us to give a finer analysis of the Barbara-form:

${ }^{8} \mathrm{~A}$ similar distinction can be found in Henry Totting of Oyta (see [6], [10]).

${ }^{9}$ Hiis tamen non obstantibus dico quod nullo sillogismo quis cogere potest ponere distributionem extra numerum que predicto argumento credebatur concludi. Dico enim illam propositionem: omnis essentia divina est persona in hoc sensu: omne ens quod est essentia divina est persona esse falsam, quia concedendum est quod trinitas est ens quod est essentia divina (bene enim sequitur: trinitas est essentia divina, ergo trinitas est ens quod est essentia divina) et tamen trinitas non est persona (MD, fo. 128ra).

${ }^{10}$ Simo Knuuttila has studied the Abelardian origin of the extensional approach [4, pp 192 - 198]. The 'omne ens quod est' is playing a similar role as the 'idem quod' device in Abelard's proposal. See also [3, p. 130] and [5, p. 73]. 
B3. Omne ens quod est A est B, omne $\mathrm{C}$ est $\mathrm{A}$,

ergo omne $\mathrm{C}$ est $\mathrm{B}$

Every being that is $\mathrm{A}$ is $\mathrm{B}$,

every $\mathrm{C}$ is $\mathrm{A}$,

therefore every $\mathrm{C}$ is $\mathrm{B}$.

And also a new formulation of the rule governing the validity of the mood Barbara:

Rule 2: A necessary condition for the validity of a Barbara syllogism is that the subject of the major premise ' $\mathrm{A}$ ' is distributed to every being which is A (omne ens quod est A).

\section{Proprietates terminorum and syllogistical form: the notion of supponere mediate}

The distinction between two kinds of universality can also be formulated in terms of suppositio, the property of terms by virtue of which they stand for something when they are used in a proposition. Pardo quotes Peter of Ailly, ${ }^{11}$ who distinguishes, as far as divine terms are concerned, between suppositing immediate and suppositing mediate. It should be noted that he is not introducing some new non-standard species of supposition, he is just distinguishing two ways in which a divine term, owing to the peculiarities of the trinitarian domain, can supposit for its supposita.

The test to distinguish whether a term is suppositing in one or the other way is one of convertibility:

- A term supposits mediate for something, say A, when the term supposits for A but it is not convertible with the corresponding term 'A' by means of the expression 'omnis res que est A.'

- A term supposits immediate for something, say A, when the term supposits for $\mathrm{A}$ and it is convertible with the corresponding term ' $A$ ' by means of the expression 'omnis res que est A.'

\footnotetext{
${ }^{11}$ From book I, question 5 of Peter's commentary on the Sentences.
}

For example, the term 'Essentia divina' supposits for the Father, but it is not convertible with the term 'Father' in the terms 'omnis res que est Essentia divina est Pater.' Thus, 'Essentia divina' supposits just in a mediated way for the Father. In contrast, the term 'Pater' does supposit immediately for the Father, as the testing proposition 'omnis res que est Pater est Pater' is true.

Pardo grounds this distinction in a parallel distinction between two ways of signifying that are peculiar to the trinitarian terms. On the one hand, each divine term has been imposed to signify something. This original imposition determines what he calls the 'primary signification' of the term. But, on the other hand, when we are talking about the Trinity, the thing which is primarily signified has some ontological connections with some other things that the term has not been imposed to signify. For example, the divine Essence, which is primarily signified by the term 'Essentia divina,' is identical with the Father. In virtue of this ontological connection, we can say that the term 'Essentia divina' also signifies the Father. But this is not by imposition, but rather by the very nature of the thing which is primarily signified. Thus, Pardo calls this a 'secondary signification.' As supposition is derived from signification, each divine term has two ways of suppositing: it supposits immediately for the things that are primarily signified, and it supposits in a mediated way for the things that are secondarily signified. ${ }^{12}$

The two kinds of universality, the one that suffices for the mood Barbara to be a formal consequence and the one that does not suffice, can thus be formulated in terms of supposition. If the subject of the major premise is taken as standing for just the things that it immediately supposits for, then the universality will not be sufficient for the requirements of formality. Instead, in order for the syllogism to be governed by the dici de omni, the

${ }^{12}$ Et si dicas secundum istum modum dicendi quomodo declaranda est illa duplex suppositio premissa, mediata scilicet et immediata. Respondeo: suppositio ex significatione cognoscenda est, ideo cum ponatur talis duplex suppositio conformiter ponenda est duplex significatio: una primaria, secundum quam terminus ab impositore habet ut aliquid det intelligere, et cum iste terminus pater ab impositore non habet nisi quod significet patrem, ideo cum supponat pro patre immediatam suppositionem habet. Sed secundario significat rem idemptificatam cum illa re ad quam primo est impositus ad significandum, et hoc non est propter impositionem sed propter naturam rei significate que talis est ut habeat talem idemptitatem $(M D$, fo. $127 \mathrm{vb})$. 
subject of the major premise has to be taken as standing for both the things that it immediately and mediately supposits for

This is how Peter of Ailly's distinctions, which he had used to solve his theological problems, are used by Pardo in his attempts to solve a logical problem: the sharpening of the notion of syllogistical form. Again, the General Rule can be specified for the case of the mood Barbara by means of the following formulation:

Rule 3: A necessary condition for the validity of a Barbara syllogism is that the subject of the major premise is taken as standing for both the supposita that it immediately and mediately supposits for.

Both the notion of complete distribution and the notion of mediately suppositing are formulated with the help of the complex expression 'omne ens quod est' (or the equivalent 'omnis res que est'), which extensionalises the analysis in a way that is comparable with the modern quantificational approach. With this tool, one can provide an analysis of the trinitarian examples which dissolves their paradoxical character. But, before the logical value of this expression is definitely established, it has to overcome some difficulties.

\section{Latin as a tool for analysis. The supposition of the term 'Pater'}

In fact, Pardo does not accept the notion of completa distributio without discussion (along with the corresponding notion of supponere mediate), when it is spelled out by means of the expression 'omne ens quod est.' These notions, useful as they have proved to solve the theological problems, both raise some logical problems to which the logician must pay attention.

First, Pardo poses an objection against the notion of supponere mediate: it seems that it could be said that the term 'Pater' supposits for the Son, once it has been admitted that the term 'Pater' supposits for the divine Essence. ${ }^{13}$

\footnotetext{
${ }^{13}$ Sed probaretur apparenter contra istum doctorem quod iste terminus pater mediate supponit pro filio si iste terminus pater mediate supponat pro essentia. Sic enim arguo: pater supponit pro omni ente quod est pater et pro eo distribuitur si completa distributione distribuatur, sed filius est ens quod est pater (sequitur enim: est essentia,
}

The point is how far we can go with the possibility that ontological connections would extend the supposition of the terms beyond that which they have been imposed to signify. If the identity of the Father with the Essence leads one to admit that the term 'Pater' mediately supposits for the Essence, then it could be thought that the identity of the Essence with the Son would further lead one to admit that the the term 'Pater' mediately supposits for the Son.

Pardo reports that some theologians were overcome by this objection, and that they therefore added a new distinction within the notion of mediate supposition: 'primary' mediate supposition and 'secondary' mediate supposition. When a term is taken in primary mediate supposition, it supposits for the thing which is identical to the immediate suppositum. When a term is taken in secondary mediate supposition, it supposits for the thing which is identical to the thing which is identical to the immediate suppositum. It seems as if the ontological connections would allow for limitless new supposita (that is, if 'Pater' supposits for the Essence, the identity of the Son with the Essence forces one to admit that 'Pater' also supposits for the Son), although the logical distinction between 'primary' and 'secondary' seems to safeguard the idea that the Father is not the Son. But Pardo does not agree with this limitless extension of the supposita of a divine term.

This problem extends to the notion of complete distribution, as a term that is taken with complete distribution is taken as standing for both its mediate and immediate supposita. Does the term 'Pater' stands for the Son when it is taken with complete distribution, that is, the one required for the mood Barbara to be a formal consequence? Pardo does not want it to do that, but the problem will be very hard to solve, as what is involved here is no less than the limits of a logical analysis that is carried out by means of a natural language. The supposita of the term 'Pater,' when it is taken with complete distribution, for example in the proposition 'omnis Pater est Pater,' are determined by means of the Latin expression 'ens quod est Pater.' But the peculiar semantics of the trinitarian terms raises doubts about the adequacy

que essentia est pater), ergo est ens quod est pater, ergo iste terminus pater supponit pro filio $(M D$, fo. $127 \mathrm{va})$. 
of this natural language expression to serve the purposes it has been designed for.

In order to determine the supposita of the term 'Pater' when it is taken with complete distribution, one has to find the things of which 'this is a being which is Father' can be truly said. But in order to find this, one has to analyse the complex term 'ens quod est Pater.' Pardo uses in the analysis another terminist notion: the property of restrictio, which modifies the 'normal' supposition of a term, making it stand for fewer things than it normally stands for. Different kinds of restricting terms affect the restricted term in different ways. The question here is how the clause 'quod est Pater' is restricting the term 'ens' in the expression 'ens quod est Pater.'

Pardo reports the opinion of those who think that in the complex expression 'ens quod est Pater' the term 'ens' is restricted to standing for the same things that the term 'Pater' stands for, just as in 'ens quod est Sortes currit' the term 'ens' does not supposit for any being, but it is restricted to stand just for Socrates. But Pardo's opinion is different, again motivated by the peculiar semantics of the trinitarian terms: when the restricting term is following a copula implicationis (that is, the copula which accompanies the relative 'qui'), it does not restrict the term to stand for the thing that the restricting term stands for (in this case, for the Father), but for the thing which is the suppositum of the restricting term (in this case, for the thing which is Father), and this allows the term 'Pater' to supposit for the divine Essence. Again, a device for extensionalising the analysis ('pro ente quod est Pater') is operating. ${ }^{14}$

But the device demands that Pardo should put a limit on it. The problem is that, in order to determine the supposition of the term 'Pater' when it is used in a proposition, another supposition is involved, namely the

\footnotetext{
${ }^{14}$ Respondeo: quando aliquis terminus restringitur per terminum sequentem copulam implicationis non habet ille terminus ex vi restrictionis quod stet precise pro eodem pro quo stat precise ille terminus restringens, sed habet tantum ille terminus ex vi restrictionis ut stet pro eo quod est illud pro quo supponit ille terminus restringens, sive illud sit alia res sive non. Exemplum: ut si per impossibile ponerentur due essentie divine quarum una esset pater et filius alia vero precise esse spiritus sanctus, tunc sic dicendo: essentia divina que est pater, ly essentia divina non staret precise pro esentia que est spiritus sanctus, staret tamen pro essentia que est filius, quia essentia que est filius est essentia que est pater; nec tamen debet dici quod ly essentia stet precise pro eodem pro quo ly pater (MD, fo. 128ra).
}

supposition of the term 'Pater' which appears in the complex expression 'ens quod est Pater.' The peculiar semantics of the trinitarian terms would allow the first 'Pater' to supposit for the Son unless some limit is put on the supposition of the second 'Pater.' Pardo points out that the restricting term 'Pater' has to be taken as suppositing immediately. If it were taken as suppositing mediately, it would restrict the term 'ens' to stand for the thing which is the being which is Father (ens quod est ens quod est Pater), and this would allow the term 'Pater' to supposit for the Son (which is actually a being which is Father, namely, the Essence). The appropriate use of the notion of supponere immediate thus serves to dispel any doubts as to the adequacy of the expression 'ens quod est Pater' as a tool for logical analysis.

\section{Latin as a tool for analysis. The universality of 'omnis Pater est} Pater'

When the problem is approached in terms of the notion of distributio completa, we encounter analogous difficulties. Pardo does not want the term 'Pater' to be able to supposit for the Son, but how can he prevent the term 'Pater' from being distributed to the Son in the proposition 'omnis Pater est Pater?' The complete universal sense of this proposition will be expresed by the following: 'omne ens quod est Pater est Pater.' How should this new proposition be interpreted? Pardo finds the elements he needs for an adequate answer in the discussions of the theologians concerning the following paralogism:

(3) Omne ens quod est Pater est Pater,

Filius est ens quod est Pater,

ergo Filius est Pater,

Every being that is the Father is the Father,

The Son is a being that is the Father,

Therefore the Son is the Father, 
which seems to have the form of a Darii mood, and prima facie true premises. ${ }^{15}$ The theologians armed themselves with different logical tools in order to avoid the unwanted conclusion that the Son is the Father. Pardo examines in the first place the tools developed by Peter of Ailly, which he finds unsatisfactory.

Trinitarian paralogisms had convinced Peter of Ailly that plain universality did not suffice in order for a syllogism to be governed by the dici de omni. What is needed is that the major premise should say that 'of whatever the subject is said, of the same thing the predicate is said.' But, while in the domain of the creatures the sign 'omnis' was thought to be enough for this task, the domain of the Trinity has shown that it is not enough, and consequently that the schema 'omne A est B' does not sufficiently expresses the universal form which is required for the syllogism to be valid. Thus, Peter made a distinction between being universal simpliciter and being universal secundum quid. A proposition is universal simpliciter when the subject is distributed as a matter of form (de forma), for example, when one says 'omnis res que es A est B' or 'quicquid est A est B.' In contrast, a proposition can be said to be universal secundum quid, that is, in an improper sense, when the distribution is not formally stated, and this happens whenever one just says 'omne A est B.' This means that, according to Peter, the universal syncategorem 'omnis' does not suffice to make a proposition universal enough (sufficienter universalis) in order to be the premise of a Barbara syllogism. Thus, he proposes the introduction of some complex syncategorems, such as 'omnis res que est,' 'nulla res que est,' as needed for the complete distribution of the subject in a simpliciter universal proposition.

Once this kind of complex expression has been admitted as a universal syncategorem, Peter of Ailly is able to offer a double reading of the proposition 'omne ens quod est Pater est Pater' which is the major premise

\footnotetext{
${ }^{15}$ Et confirmatur, quia quero an ista propositio: omnis pater est pater, aut est vera in sensu de omni aut non. Si dicas quod non, ergo pro aliquo supponit subiectum pro quo non supponit predicatum et illud non potest esse nisi filius aut spiritus sanctus. Si non supponit predicatum et illud non potest esse nisi filius aut spiritus sanctus. Si
dicas quod est vera in sensu de omni, contra: sensus de omni est iste: omne ens quod est pater est pater, sed ipsum ostendo esse falsum, quia bene sequitur: omne ens quod est pater est pater, filius est ens quod est pater, ergo filius est pater. Premisse sunt vere, ergo et conclusio, et consequentia tenet in darii (MD, fo. $127 \mathrm{va})$.
}

of the example (3), depending on which part of it is acting as a universal syncategorem: a) If the syncategorem is the simple term 'omne,' then it is distributing the whole complex 'ens quod est Pater,' but then the syllogism will not be governed by the dici de omni, as the sign 'omnis' is not sufficient to make the complete distribution that is required. b) If the syncategorem is the complex 'omne ens quod est,' then it is distributing only the term 'Pater,' and then the syllogism will not be valid either, even if the distribution is indeed complete in virtue of the special syncategorem, because the subsumption in the minor premise has not been made under 'Pater' but under 'ens quod est Pater.' That is, according to Peter, the example (3) cannot be governed at all by the principle dici de omni (the problem being either one of distribution or one of subsumption).

Pardo rejects the solution of putting a special syncategorem in order to make the complete distribution of the term 'Pater,' as the effect would be too strong. A sign distributing the term 'Pater' to any being which is Father would make it stand for the Son, as the Son is a being which is Father. He prefers to think that the syncategorem in 'omne ens quod est Pater' is the usual 'omnis,' which is distributing the term 'ens quod est Pater' (where the 'ens' is restricted by the 'quod est Pater' in the way explained before). ${ }^{16}$

The solution finally accepted by Pardo is that of Gregory of Rimini, who adopts the same strategy that proved useful for solving example (1). In order for the syllogism (3) to be good, the major premise has to be de omni, and this requires the distribution to be complete. That is, the subject 'ens quod est Pater' must be distributed to everything which is a being which is Father (omne ens quod est ens quod est Pater). Read in this way, the major premise 'omne ens quod est Pater est Pater' is false and the paralogism is solved. ${ }^{17}$

${ }^{16}$ Si vero dicatur quod illa complexa: omnis res que est, nulla res que est, licet non sint sincathegoreumata supplent tamen quedam sincathegoreumata incomplexa distribuentia distributione completa. Arguitur sic: ex hoc sequitur quod ille terminus pater per illa signa quecunque sint illa distribuitur pro omni ente quod est pater et distribuitur pro filio, quia filius est ens quod est pater. Et sic habetur intentum quod iste terminus pater mediate supponit pro filio (MD, fo. $127 \mathrm{vb})$.

${ }^{17}$ Et ad sillogismum illud pretactum, cum arguitur: bene sequitur omne ens quod est pater est pater, filius est ens quod est pater, ergo filius est pater, dicitur quemadmodum dicit ille doctor qui prima facie videbatur reprobandus: quod illa 
But what is interesting is how the distinction between the two readings of 'omne ens quod est Pater est Pater' (as either de omni or not de omni) allows Pardo to save the truth of 'omnis Pater est Pater.' Again, Pardo has to put a limit on the application of the logical tools that the theologians employed within the domain of the Trinity. Although the proposition which is used to formulate the de omni sense of 'omnis Pater est Pater' (that is, 'omne ens quod est Pater est Pater') can be interpreted in a de omni sense when it is put as a premise of a syllogism, when it is employed as a tool for logical analysis it has to be interpreted according to its non-de omni sense, as this is the only way for the proposition 'omnis Pater est Pater' to be true in its de omni sense. ${ }^{18}$

We can see how the tools that the theologians had employed to solve the trinitarian paralogisms are being used by a logician to give the specific sense of the Latin expressions which are operating as metalinguistic devices for logical analysis. Pardo discovers that the same logical distinctions that are applied to the problems raised in the trinitarian domain by the object-language expressions can be applied to the problems raised by the metalinguistic expressions which spell out the sense of the objectlanguage expressions. With the help of these tools, Pardo is able to establish the logical value of the complex terms 'ens quod est Pater' and 'omne ens quod est Pater' as a tool for the analyis of the supposition and of the complete distribution of the object-language terms, respectively. Thus, the distinctions that Pardo has found in the theological discussions can be employed by the logician not only as a tool for the logical analysis of the syllogistical form, but also for the assessment of the very logical devices that are being used in this analysis.

\section{Conclusion: What has to be said about syllogistical form?}

maior est distinguenda. Aut est de omni seu completa distributione distribuitur, et tunc maior est falsa, quia sensus est: omne ens quod est ens quod est pater est pater, et hoc est falsum. Si vero subiectum distribuatur incompleta distributione maior est vera, sed non sequetur quod non regulatur per dici de omni (MD, fo. $128 \mathrm{ra}-\mathrm{b})$.

${ }^{18}$ Est igitur talis ordo: nam ista propositio omnis pater est pater est vera sive sit distributio completa sive incompleta. Et iterum, sensus que habet ut in ea est distributio completa est distinguendus, pro eo quod subiectum talis sensus potest distribui complete et incomplete, et ibi est status (MD, fo. 128rb).
As a final objection to this whole approach, Pardo raises the question: is the mood Barbara a formal consequence? The naive objector would say that it is not, as we can construct a syllogism with a Barbara-form with true premises and false conclusion. In fact, the distinctions of the theologians have shown that there is a reading of the premise 'omnis essentia divina est Pater' that makes syllogism (1) to have true premises and false conclusion. The naive objector would say that syllogism (1) has the same form as the following, an impeccable example of the Barbara-form:

(4) Omne animal est substantia,

omnis homo est animal,

ergo omnis homo est substantia.

Every animal is a substance,

every human being is an animal,

therefore every human being is a substance.

Thus, either the tools used by the theologians are defective, or syllogistical inferences are not actually formal consequences, but they hold in virtue of the material elements of discourse.

But, needless to say, Pardo thinks that there is more to logical form than meets the eye, and therefore a better understanding of formality is needed to escape from the dilemma. The elements of the logical form that are usually taken into account are not sufficient to overcome every objection against the formal character of the syllogism. In contrast, Pardo will take considerable time specifying the elements which are relevant to the form. For the moment, in the light of the trinitarian paralogisms and as far as the Barbara-form is concerned, Pardo has made it clear that the kind of distribution (complete / incomplete) has to be taken as an ingredient of the syllogistical form. ${ }^{19}$

If the kind of distribution belongs to the syllogistical form, syllogism (1) can only be said to have the same form as syllogism (4) in the case where

${ }^{19}$ Pardo deals separately with the expository syllogism, in which the middle is a singular term. The peculiarity of the trinitarian semantics (a singular term can supposit for more than one thing) will eventually call into question the very possibility of constructing a valid expository syllogism with trinitarian terms ( $M D$, fo. 139vb-143ra). 
both major premises are interpreted with complete distribution. ${ }^{20}$ According to Pardo, the actual form of the mood Barbara is not B1, as logicians were inclined to think before they were confronted with the triniarian domain, but B3, which is the one that includes the complete distribution as a further component of the syllogistical form. This is an example of how the discussions of the theologians have helped the logician with the (endless?) task of revealing the logical form.

\section{Acknowledgments}

I would like to thank Ángel d'Ors and Heikki Kirjavainen for helpful comments on the draft of this article. I am also grateful to Hester Gelber, Alfonso Maierù, Olli Hallamaa and Simo Knuuttila for kindly having provided me with some material to complete my research.

\section{References}

[1] Ebbesen, S., The Semantics of the Trinity According to Stephen Langton and Andrew Sunesen, [in:] J. Jolivet \& A. de Libera, eds., Gilbert de Poitiers et ses contemporains. Aux origines de la 'Logica Modernorum', Bibliopolis, Napoli, 1987, $401-435$.

[2] Hallamaa, O., Defending Common Rationality: Roger Roseth on Trinitarian Paralogisms, Vivarium 41/1, 2003, 84 - 119.

[3] Knuuttila, S., The Question of the Validity of Logic in Late Medieval Thought, [in:] R. Friedman \& L. O. Nielsen, eds., The Medieval Heritage

\footnotetext{
${ }^{20}$ Respondeo: de formalitate consequentie respondere valde tediosum est quemadmodum in materia de descensu pertractabitur. Si enim que communiter ponuntur ad formalitatem consequentie sufficerent, difficile esset salvare multas cavillationes quibus probaretur sillogismum non esse formalem consequentiam, sed de hoc alias. Sed ad predictam instantiam aliqui [Buridanus] respondent dicentes sillogismum non esse formalem consequentiam <nisi> medio sumpto cum hac implicatione: ens quod est. Aliter forsitan posset dici quod tales sillogismi non sunt eiusdem forme nisi in utroque sit completa distributio. Si autem in neutra eorum sit completa distributio neuter eorum est bonus. Et quod variatio distributionis variet formalitatem consequentie ostenditur, nam suppositio videtur se tenere ex parte forme consequentie (MD, fo. $128 \mathrm{rb})$.
}

in Early Modern Metaphysics and Modal Theory, 1400-1700, Kluwer Academic Publishers, Dordrecht, 2003, 121 - 142.

[4] Knuuttila, S., How Theological Problems Influenced the Development of Medieval Logic, [in:] S. Caroti et al., eds., 'Ad ingenii acuitionem': Essays in Honour of Alfonso Maierù, F.I.D.E.M., Louvain-la-Neuve, 2006, $183-198$

[5] Knuuttila, S., Trinitarian Fallacies, Identity and Predication, [in:] P. Kärkkäinen, ed., Trinitarian Theology in the Medieval West, LutherAgricola-Society, Helsinki, 2007, 69 - 87.

[6] Maierù, A., Logica aristotelica e teologia trinitaria. Enrico Totting da Oyta, [in:] A. Maierù \& A. Paravicini Bagliani, eds., Studi sul XIV secolo in memoria di Anneliese Maier, Edizioni di Storia e Letteratura, Roma, $1981,481-512$.

[7] Maierù, A., Logique et théologie trinitaire: Pierre d'Ailly, in Preuve et raisons à l'Université de Paris. Logique, ontologie et théologie au XIV siècle, Z. Kaluza \& P. Vignaux, eds., Vrin, Paris, 1984, 253 - 268.

[8] Maierù, A., A propos de la doctrine de la supposition en théologie trinitaire au XIVe siècle, [in:] E. P. Bos, ed., Medieval Semantics and Metaphysics. Studies Dedicated to L. M. de Rijk on the Occasion of His 60 Birthday, Ingenium, Nijmegen, 1985, 221 - 238.

[9] Maierù, A., Logique et théologie trinitaire dans le moyen-âge tardif: deux solutions en présence, [in:] M. Asztalos, ed., The Edition of Philosophical and Theological Texts from the Middle Ages, Almqvist \& Wiksell, Stockholm, 1986, 185 - 212.

[10] Shank, M. H., 'Unless You Believe, You Shall Not Understand': Logic, University and Society in Late Medieval Vienna, University Press, Princeton, 1988. 